\title{
The Interaction Between Protean Career Orientation, Career Goal Development And Well-Being Outcomes: Evidence From Professional Engineers
}

\author{
Norizan Baba Rabim ${ }^{* a}$ \\ ${ }^{a}$ Universiti Sains Malaysia (USM), Malaysia
}

\begin{abstract}
Experiencing strong personal development and growth are important for engineers, compared to professionals in other fields. Nevertheless, if career goal development behaviour is not present in sufficient quantities, engineers would be at risk if their own goals and expectations are not aligned with the companies they are working for. As a result, it may have a negative impact on their well-being. In this article, a sample of professional engineers $(\mathrm{N}=387)$ were utilised to examine the relationship between protean career orientation towards career goal development, career satisfaction and psychological well-being and to examine the mediating effect of career goal development between protean career orientation toward career satisfaction and psychological well-being. The research model was tested using the goal setting theory. The results of a partial least square (PLS) regression demonstrated that protean career orientation had a positive effect towards career goal development; subsequently career goal development had a positive effect on career satisfaction and psychological well-being. On the other hand, career goal development was found not to mediate the relationship between protean career orientation towards career satisfaction and psychological well-being. Based on the findings, this research suggests employers and industries encourage their unlicensed engineers to register as graduate engineers, so that later they can upgrade themselves to professional engineers' status, as eventually this would help them to experience their job in a more meaningful way, and consequently increase their work happiness.
\end{abstract}

Keywords: protean career orientation; well-being; career goal development

JEL Classification: M1, I2, I3 


\section{Introduction}

The world of employment is transforming and so is the essence of the career of an engineer, who is recognised as an expert in his/her line of work and is usually very career-oriented, with high expectations from his/her job. Furthermore, engineers carry most of the responsibility for planning and managing their careers. Thus, according to Hall, Yip, and Doiron (2018), protean career orientation is an appropriate mindset for engineers' present work conditions. Engineers do not wait for their employers to develop their future; instead they build their own careers. Hall et al., further stated that values like freedom and adaptability are showcased as self-directed perspectives under a protean career orientation. On the other hand, Lo, Pluviano and Briscoe (2018) posited that by managing one's own career development, various favourable effects can be achieved. Career satisfaction and well-being are the two most common career psychological outcomes.

Employers structure an engineer's key performance areas, as they also do for other workers, based on business requirements, increases in productivity, and workplace changes. As stated by Malan (2004) in Rahim and Siti-Rohaida (2015), these key performance areas are an essential part of an engineer's work life. Engineers must be skilled at organising technical teams, manoeuvring intricate nonlinear systems, and solving problems. For instance, Trevelyan (2007) explained that an effective engineer is capable of working with and influencing other workers to diligently carry out their tasks, based on a schedule agreed by all. The scholar's emphasis on technical coordination was stressed in other studies, which also emphasised the significance of effective communication. In previous research comparing engineering professionals' design work, it was discovered that engineers managed to gather more information, in more categories, as they defined the scope of the problems they faced. It was also determined that engineers were more cautious when they needed to consider a problem's context and constraints.

Engineers in Malaysia have greatly contributed to the economic development of the nation. Malan (2004) mentioned that they play an important role in numerous industries like construction, manufacturing, and agriculture-based industries. Furthermore, the engineering sector is said to provide essential support for the country's economic transformation (Kelly Services, 2012). Nonetheless, the engineers' influence on people's lives comes with a huge responsibility. As stated in 2002 by the Board of Engineers Malaysia (BEM), every engineered item must be safe and useful. However, the statistics reported from several sectors contradict the concept and expectation of the BEM. For example, the accident rate in Malaysia's construction sector is high, based on statistics by the BEM's Human Resources Department (Hamid, Majid, and Singh, 2008). It was reported that the highest number of fatalities (34\%), in the construction sector, involved people falling from high places, followed by those struck by falling objects $(25 \%)$ and striking against or being struck by objects $(10 \%)$. These figures depict that the organisations the engineers were attached to had failed to ensure the physical safety of their workers, which affected their physical and psychological well-being. Hence, this issue could signify a serious problem if poor well-being is shown to be linked to accidents, poor health, and safety (Lee and Migliaccio, 2018). 
Gadjah Mada International Journal of Business - Jan.-April, Vol. 22, No. 1, 2020

\section{Gaps in the Study}

Engineers are fast-track individuals who have special knowledge and expertise. Thus, they have great expectations and ambitions for their careers (Malan, 2004). Engineers are also known to energetically climb their career ladder. Being protean careerists, they strive for psychological success. To achieve success, they set themselves challenging goals by engaging in career goal development behaviour (Hall, 2002). These behavioural components are within the control of the individuals. Unfortunately, the combination of being visionaries, ambitious, having their own goals and expectations are sometimes not aligned with those of the companies they are working for. Schaufeli and Bakker (2001) emphasised that if engineers struggle with the complexities of their jobs, they may feel their jobs are meaningless. Thus, the conflict between fulfilling the work demand structured by the organisation and also being visionaries, ambitious, having their own goals and expectations, all have an influence on the well-being of engineers. As such, this present study aimed to investigate the relationship between protean career orientation towards career goal development and well-being outcomes (career satisfaction and psychological well-being). In addition, career goal development was examined for its mediating effect between protean career orientation and well-being outcomes, which are engineers' career satisfaction and psychological well-being. Accordingly, the following research questions were posed to further examine the issue:

1. Does protean career orientation influence career goal development among professional engineers?

2. Does career goal development influence career satisfaction among professional

\section{engineers?}

3. Does career goal development influence psychological well-being among professional engineers?

4. Does career goal development mediate the relationship between protean career orientation and career satisfaction among professional engineers?

5. Does career goal developmhent mediate the relationship between protean career orientation and psychological well-being among professional engineers?

\section{Literature Review}

\section{Protean Career Orientation}

Progress in the job market and economy has created better salaries and allowed more freedom in choosing a job. Additionally, frequent job or career changes have become more common and are a key attribute of modern careers. Past studies listed several reasons why a person decides to change their job, like family commitments and looking for better salary packages (Lysova et al., 2019). Hence, a person gets the opportunity to work for different corporations, which could involve different work roles and experiences, while it is also common to be employed in different areas and industries. As mentioned by Guan et al., (2019), working long-term for just one organisation or company is becoming rare. Therefore, individuals need to carefully plan their career paths. To do so, individuals can invest in professional career development, besides learning from the experience gained at the beginning of their careers.

There are several theoretical perspectives that have been applied by researchers to 
study careers. First, one's career is often seen as being connected with social functioning (Dickmann et al., 2018). It is also considered as a profession and a way to achieve self-development and self-enrichment. Meanwhile Frieder, Wang and Oh (2018) focused on the connection between employees' personalities and their career choices. They reported that the more compatible an individual's job is with his or her personality, the more efficient and motivated he or she will be; which will benefit both the person and their employer.

In research into careers, the focus is on protean careers. Protean careers are a two-dimensional framework, in which a person, instead of the organisation, possesses total control of his or her career's development (Briscoe and Hall, 2006a, 2006b). Such individuals are self-directed, whereby they take on proactive and independent roles in managing their vocational behaviour. Not only that, in making decisions regarding their own careers, they prefer to depend on their own values rather than referring to some external standards. Moreover, a protean career orientation allows greater mobility, presents a holistic view of life, and encourages progressive development, as asserted by Briscoe, Hall, and Demuth (2006). Therefore, the key criterion for a career is subjective since it is motivated by personal values.

The current erratic employment situation affects research into careers. Due to this, workers' expectations of their jobs and what they desire from their careers have changed. Furthermore, local and global economies are always going through transformations. Suvaci, (2018) stated that retrenchment, due to company downsizing and high competitiveness in the job market, encourages people to work harder since they think underperforming in their job could get them fired. As such, people have devised career strategies to gain more useful work experiences and allow their personal needs to grow (Stauffer et al., 2019). This corresponds to protean career success, which is assessed via feelings of personal achievement and career fulfilment. Besides, Hall and Moss (1998) described the protean approach as 'a path with heart' because it integrates work with life values.

\section{Career Goal Development}

Career goal development encompasses the goals, like promotion, increases in salary, and the development of skills, pursued by people at their workplace (Noe, 1996; Zikic and Klehe, 2006). Locke and Latham's (2006) goal setting theory is pertinent to comprehend how goals can affect career-oriented behaviour, since it posits that the goals influence the behaviour by retaining one's attention, motivating and preserving one's efforts and enabling the advancement of strategies needed to accomplish such goals. It is widely accepted that workers who carry out tasks based on detailed and challenging goals are more efficient and productive compared to others who do so by relying on vague, simple or non-existing goals (Latham, 2016). In addition, Latham stated that a worker's wish to achieve career-related outcomes like promotion, salary raises or gaining new skills, demonstrates his or her career goals. An emphasis on one's goals could be a crucial determinant in realising them, enjoying the fulfilment of career advancement, and participating in activities concerning their accomplishment (Xueling, 2017).

Goals are any provable and measurable outcome or aim of an action or behaviour. Hence, based onh Locke's basic assumption, goals can regulate a person's behaviour. To achieve a specific goal, an in- 
dividual must synthesise the direction, show effort, and develop persistence to successfully carry out the assigned tasks by maximising the goal setting, focus on specific and stimulating goals and giving their best effort over time. The more challenging the goals are, the higher a person's achievement is, based on the commitment to deliver results according to the set goals. Hence, to maximise his or her performance to realise those goals, support from the management is necessary. The support needed includes providing quality feedback, effective reward mechanisms, and the necessary resources including enough time to complete the given tasks and the required training and materials. To achieve this, Locke (1984) recommended seven steps to enhance the setting of goals: (1) identify each task's objectives that must be achieved; (2) specify how the task's performance will be assessed; (3) describe the standards that must be adhered to, to realise the goals; (4) recognise the time frame needed to complete the task; (5) prioritise the task's goals; (6) create a rating scale based on the goals' difficulty and significance to the task; and (7) determine the coordination necessary for completion of the task.

Stumpf et al., (1984) described focusing on goals as the extent to which a person is confident of his or her career goals or preference for a specific job or organisation. It is a vital indicator of an individual's developmental behaviour and acceptance to partake in developmental activities. Apart from that, Locke et al., (1981) argued that goals influence behaviour via accommodation of the progress of goal accomplishing strategies. One of those strategies is the participation of workers in actions and activities that can help them increase their strengths and lower their weaknesses. The more focused a person is in realising his or her career goals, the more likely it will be for them to perform actions that can assist them in reaching their goals and developing a stronger motivation to take part in developmental activities.

Locke and Latham (2006) described that goals concern the use of main standards like feeling content with one's performance to influence the set goals. Thus, motivation can be developed by setting high or hard goals because such goals will provide more fulfilment when accomplished. As such, experiencing success at the workplace suggests that the employee realises that he or she can progress and face job challenges by pursuing and achieving significant and meaningful goals. Locke and Latham (2006) further stated that feedback can act as the key mediator to set a goal, since employees require feedback that reveals their progress and commitment to the goal. Besides, this can be enhanced through self-efficacy and being aware of the task's importance and complexity and knowing that gaining knowledge to complete a task is harder for tasks that are complex and that a need to overcome certain limitations exists. Moreover, goals' effects can be moderated when the resources necessary to finish a task are unavailable, whereas an employee's performance is influenced by the goals only when there is minimal excessive work (Ogbeiwi, 2018).

\section{Career Satisfaction}

Based on the protean career theory, nowadays people possess a higher level of personal control over choices concerning their careers (Briscoe and Hall, 2006a). Certain studies, like the one conducted by Sargent and Domberger (2007), have highlighted that a proactive and self-driven worker experiences more career satisfaction. Greenhaus, Parasuraman, and Collins (2001) defined career satisfaction as a pleasurable or positive emotional state arising from the as- 
sessment of one's work experiences. On the other hand, Loi and Ngo (2018) asserted that this satisfaction is a subjective perception and assessment of an individual's career development and achievement, while Cha et al., (2017) stated that this is typically the most important element in a person's career.

Barnet and Bradley (2007) explained that career success is usually assessed as career satisfaction, whereas Hirschi et al., (2016) argued that the significant predictor of a person's satisfaction with his or her career includes the material and social support necessary to realise his or her personally driven objectives. Thus, it is more complicated for a company to prescribe a career point and other growth opportunities when career success is seen as a self-driven, psychological accomplishment rather than a person's mobility through organisational ranks. This is because an individual's goals for growth are usually unique and need their own action plan.

Academics like Judge et al., (1995) support that career satisfaction originated from the concept of career success. In their studies, career success was depicted as positive psychological or work-related goals or achievements realised due to work experiences. Career success can be seen through objective and subjective perspectives. The objective perspective involves observable career accomplishments such as one's gratuity or salary, progress in the organisational hierarchy, or promotion (Kraimer et al., 2001). A person's career satisfaction is reflected by his or her view and assessment of his/her career-related achievements. Hence, based on the subjective perspective, an individual's career success hinges on his or her values and is reflected based on which values, attitudes, and goals are deemed important.

In general, comprehension of career success is based on the developmental stage theories (Kwake et al., 2019). These studies reported that different stages of a person's career growth play a role in forming their experiences for career choices. It is assumed that the individual is pursuing a set of predictable work experiences in one company or job. Such assumptions predicting an individual's sequence and timing of career stages have permitted companies and employees to assess their career success based on the level reached in the organisational hierarchy in a certain time frame. This intensifies the conventional perceptions that a person's rapid success and mobility up a typical organisational hierarchy is the key indicator of how successful the person's career is (Feldman, 2000). He further explained that objective career goals based on tangible accomplishments like a high salary and status and promotion to a higher rank have been dominating the literature on comprehending and evaluating individual career success.

Career satisfaction has been used as an indicator of subjective career success because career satisfaction can evocatively reflect employees' attitudinal responses about their career, based on their respective appraisals. This conceptualisation is similar to the boundless concept of careers, which is making it hard for people to define and assess career success. On the other hand, Spurk (2019) stated that career satisfaction can be evaluated via a person's satisfaction with global career success, or through measuring the intrinsic and extrinsic aspects of his or her career. This comprises salary, promotion opportunities, and scope for progress. Hence, the bound- 
Gadjah Mada International Journal of Business - Jan.-April, Vol. 22, No. 1, 2020

less career concept needs a subjective career approach whereby individuals can personally define and evaluate their career success.

\section{Psychological Well-Being}

As cited in Ashleigh et al., (2018), various factors like health, marriage, family, work, finance, educational opportunities, self-esteem, creativity, and trust in others determine one's quality of life and involve a complex mix of physical, mental, and social well-being like happiness and satisfaction. These are key features for subjective well-being, besides the subjective and positive measurement and comprehensive assessment of all the elements in an individual's life.

There are two components of psychological well-being, i.e. hedonic and eudemonic. Hedonic concerns experiencing pleasurable feelings in one's life. This forms an elevated state of happiness which nurtures positive emotions. On the other hand, eudemonic indicates that well-being does not involve maximising positive experiences; rather it concerns living fully for the ideal growth of human potential (Ryan, Huta, and Deci, 2008). Thus, eudemonic is conceptualised as experiencing enriching activities and personal growth.

Hedonic's origin is from Greek philosophy. Ryan et al., (2018) explained that hedonism focuses on fulfilling life's objectives by experiencing, as much as possible, pleasure that is oriented towards enjoyment and noble activities. This means happiness can be compared to the sum of pleasurable moments. Hence, according to modern psychology, the salient concept formed from the hedonistic point of view is subjective well-being, which typically consists of two elements. The first is the affective balance that is obtained by deducting the negative feelings rate from the positive emotions rate, whereas the second one is the perception of satisfaction with life, which according to Diener, Lucas, and Oishi (2018), is more constant and possesses a better cognitive component. Not only that, satisfaction with life is a universal verdict on life itself. This implies that emotional balance is related to the relative number of pleasant or unpleasant experiences; therefore, these concepts are inexplicably connected to the hedonistic view (Ryff, 2018).

In contrast, Sheldon et al., (2010) contends that the eudemonic concept has established that well-being derives from conducting behaviour that parallels the deep values that represent a total commitment to making people feel alive and real. Apart from that, considering whether human eudemonic perceptions can be assessed, or do they exist as rhetorical and immeasurable elements, can be appropriate. Sun (2017) is one of the influential scholars who has researched the eudemonic approach. She has claimed that a theoretical basis for measuring the notion of well-being is missing and most have overlooked crucial issues concerning its positive functions. Thus, the term 'psychological well-being' allows separation from subjective well-being, which is more representative of the hedonistic concept. Moreover, Joshanloo (2019) had tried to overcome the limitations and describes well-being as the growth of a person's true potential. As such, a person's key inspiration would be to have a well-lived life instead of happiness or psychological well-being.

Ryan, Soenens, and Vansteenkiste (2018) stated that eudemonic's emphasis is on obtaining a specific result, or specifically achieving its negative effects, in addition to a wholesome feeling of satisfaction with one's 
life. Nevertheless, over time, these points of view amongst scholars have changed and the paradigm of psychological well-being has become more holistic, instead of philosophical. As such, this current study measured psychological well-being as the overall effectiveness of an individual's psychological function (Berkman, 1971a, 1971b).

Psychological well-being can also be about living a good life and it is a combination of feeling positive and being able to function efficiently every day. However, a person's sustainable well-being does not need him or her to feel good all the time, since experiencing painful emotions like disappointment, failure, and grief is part of life (Wright and Cropamzano, 2000; Berkman, 1971a). Thus, the capability to handle these negative or painful emotions is vital for a person's long-term well-being. Psychological well-being balances the negative emotions and is inexplicably connected to an individual's ability to function in his or her daily life. As mentioned by Warr (1990), feeling good comprises positive emotions like happiness and contentment and other emotions such as interest, engagement, confidence, and affection. Therefore, an individual's ability to efficiently function psychologically involves developing his or her potential, possessing some level of control over their life, having a sense of purpose such as working towards a specific goal and experiencing positive relationships.

Theoretical and empirical studies have highlighted the significance of psychological well-being. Over the years, researchers have regularly emphasised isolating and defining the main features of the psychological well-being construct. Nonetheless, elucidating the configuration of psychological well-being is not easy nor is it straightforward. As mentioned by Jibeen (2019), this is clearly shown by the numerous terms used to discuss the construct, like emotional well-being, mental well-being, and affective well-being. This is also evident through the many conceptual approaches that have been developed.

\section{Hypotheses Development}

\section{The Effect of Protean Career Orienta- tion on Career Goal Development}

According to DiRenzo (2010), people with a protean career orientation will proactively form a suitable career goal to freely direct their career path. However, those who do not will adapt themselves to organisational goals or depend on their managers to allocate specific goals for their development and performance (DiRenzo, 2010). Briscoe et al., (2006) stated that individuals with a protean career orientation typically have unique goals and standards to attain success. They will take the initiative to create specific goals that can guide them towards fulfilling their values due to their self-directed and values-driven attitudes. Even though there are very few studies which examine the connection between protean career orientation and career goal development, establishing clear goals is believed to be an important factor in proactive career planning and a possible manifestation of one's desire for personal agency over career growth (Abele and Wiese, 2008). With these considerations, protean career orientation (self-directed and values-driven) is expected to positively influence career goal development. Hence, the following hypothesis has been formulated:

H1: Protean career orientation has a positive influence on career goal development. 
Gadjah Mada International Journal of Business - Jan.-April, Vol. 22, No. 1, 2020

The Effect of Career Goal Development on Career Satisfaction

Crant (2000) explained that career goal development concerning career progress must engage and prepare individuals to be proactive in trying to achieve their goals. Career goal development is described as a deliberate process whereby goals are interpreted into guidelines for implementation (Grant and Ashford, 2008). This aspect of career-related proactivity signifies a crucial phase in the proactive behaviour process, since it allows people to link what they anticipate psychologically with concrete behavioural steps and plans. Furthermore, this can include thinking about the type of job or work environment that will enable people to realise their goals. This indicates that career goals are associated with career planning in the sense that they impart an encouraging influence and contribute towards career strategy development (Crant, 2000). As such, it is expected that career goal development would have a positive influence on career satisfaction; hence the following hypothesis is proposed:

\section{H2: Career goal development has a positive influence on career satisfaction.}

\section{The Effect of Career Goal Develop- ment on Psychological Well-being}

Career focus is a vital determining factor of developmental behaviour and readiness to participate in development activities. The more focused an individual's career goals are, the more likely it is that he or she will engage in behaviour that can aid in achieving the goals and improving his/her enthusiasm to participate in development activities. De Vos and Soens (2008) reported that people who reflected more actively on their career goals and had a clearer vision of what they wanted to accomplish during their career, experienced a higher level of career success. Additionally, self-managing employees were more likely to attempt to achieve their desired career goals, which then made them feel more successful in their careers (Arthur et al., 2005). As mentioned by Sugalski and Greenhaus (1986), in career literature, goal focus has been portrayed as a significant determinant of career goal realisation and satisfaction with the growth of one's career. Hence, a career goal is expected to affect the level of a person's psychological well-being. Thus far, research into the theoretical relationship between career goal's development and psychological well-being is limited. Based on this assumption, the following hypothesis has been formulated.

\section{H3: Career goal development has a positive influence on psychological well-being.}

\section{The Mediating Effect of Career Goal Development between Protean Career Orientation and Career Satisfaction}

According to Guthrie et al., (1998) and Dougherty et al., (2008), it is important for individuals to adopt proactive career behaviour that suits their personality, because it will help them to be successful in their career. For example, self-initiated individuals engage in seeking social support (one type of career strategy) because they are sociable and like to make friends and have the capability to expand their network to get valuable career information, which can be important to achieve career satisfaction (Hall and Moss, 1998). Lent and Brown (2006) supported this point, that individuals who are managing their career development could affect their interests. Such interests can promote career-rel- 
evant choices, collect information about values, identify a career goal, and engage in career strategies. Therefore, career goal development is expected to mediate the relationship between protean career orientation and career satisfaction. With these considerations, the following hypothesis is proposed:

H4: Career goal development mediates the relationship between protean career orientation (self-directed) and career satisfaction.

\section{The Mediating Effect of Career Goal Development between Protean Career Orientation and Psychological Well-Be- ing}

Individuals with a protean career orientation are always highly optimistic. They experience optimism when it comes to managing the appraisal of a situation and the resulting emotional response and could increase the psychological well-being (Briscoe and Hall, 2008). De Vos and Soens (2008) have proven in their research that the impact of a protean career attitude on career success is indirect, in other words, it operates through career self-management. Since limited research has been conducted with regard to the mediating effect of career goal development behaviour on the relationship between protean career orientation and psychological well-being, the following hypothesis is proposed:

\section{H5: Career goal development mediates the relation- ship between protean career orientation and psychological well-being.}

Based on these testable hypotheses, the following conceptual framework was proposed for the research (see Figure 1).

Figure 1. Research framework $\mathrm{H}_{2}$

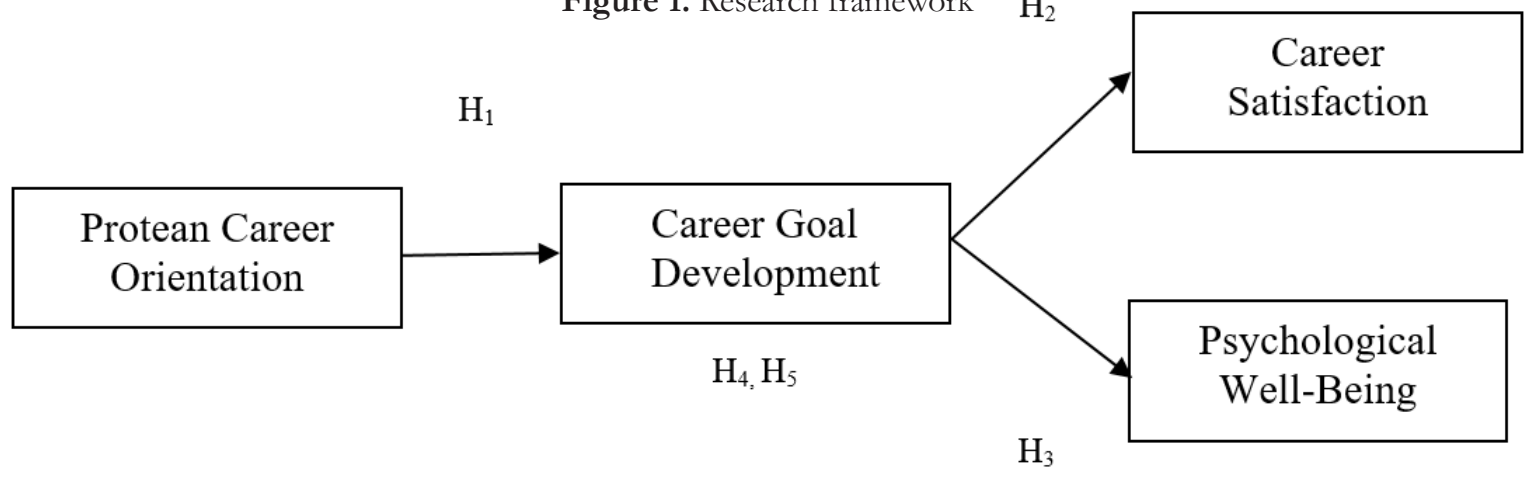

their careers (Lovalla and Kahneman, 2003). They objectively assess their own strengths and develop career strategies accordingly. Because of the tendency of individuals to choose behaviour that is in line with their attitudes, protean career attitudes lead employees to engage in certain career development behaviours that in turn result in important individual work outcomes (De Vos and Soens, 2008). The ability to cope with problems has the potential to mediate between

\section{Methods}

\section{Sampling Technique}

This research was conducted using a purposive sampling technique. It is considered the most appropriate method for this study as it examines protean career orientation, career goal development, career satisfaction and the psychological well-being among professional engineers. According to 
Sekaran and Bougie (2010), purposive sampling involves the choice of subjects who are in the best position to provide the information, either because they are the only ones who have it, or they conform to some criteria set by the research. The unit of analysis was professional engineers who were members of the Board of Engineers Malaysia (BEM) and who conform to the following inclusion criteria: a) they are graduate engineers who have satisfied the training requirements of BEM; b) have passed BEM's Professional Assessment Examination (PAE) or have been elected as a corporate member of the Institution of Engineers Malaysia (IEM); and c) have accumulate 50 Continuing Professional Development (CPD) training hours conducted by the IEM per year to maintain their professional engineer status.

Hall's (1976) idea concerning protean career orientation is similar to the requirements for professional engineers. Hall explained that a protean career orientation comprises of all the verified experiences of an individual, from their education, training, and working in several organisations, which also consists of changes in the occupational fields. Moreover, Hall (2002) stated that the protean career approach is based on continuous learning. Hence, these professional engineers must fulfil the criteria of protean career orientation; therefore, they were selected as this study's sample.

\section{Population and Sample Size}

The target population in this research was professional engineers who are members of the Board of Engineers Malaysia (BEM). For determining the minimum sample size for actual data collection, this study referred to the rule of thumb, as suggested by Hair et al., (2010), which recommends that the minimum requirement for a sample's size is to have at least five times as many observations as the number of variable items to be analysed. However, a more acceptable sample size is to have a 10:1 ratio which means ten respondents to one observed variable item. In this study, the total number of items to measure all the variables is 31 . Hence, the acceptable minimum sample size is 10 multiplied by 31 items, which equates to 310 respondents.

\section{Data Collection Procedure}

To gather the data, the drop off/pickup method was employed to hand deliver a self-administered questionnaire. By using this method, it ensured that the respondents were present to answer the questions, since the questionnaires were hand delivered by the researcher (Steele et al., 2001). Professional engineers are required to partake in CPD activities because it is necessary for them to collect an average of 50 hours of CPD annually to renew their practising certificates. CPD constitutes the systematic maintenance, enhancement, and expansion of knowledge and skills and the growth of personal attributes for the execution of professional and technical duties throughout an engineer's working life. As such, since IEM has been executing all these functions, their permission to distribute our questionnaires to professional engineers during their CPD activities was sought. Based on the scheduled activities retrieved from IEM's website, 600 questionnaires were distributed. Out of these 600 questionnaires, only 458 questionnaires were received from the respondents. Of these 458 sets of questionnaires, only 387 questionnaires were useable. The other 71 questionnaires were discarded for reasons of: (a) uncompleted data (21 cases), (b) questionnaires answered by a new registered graduate engineer (GE) 
with BEM (17 cases) and (c) the total of CPD hours collected by the respondents for the year 2013 was less than the required 50 (33 cases). As a result, only 387 cases were deemed adequate and useable for data analysis.

\section{Measures}

Most of the measures applied in this research were based on those reported in past studies with acceptable reliabilities. Fourteen items developed by Briscoe et al., (2006a, 2006b) were used to measure protean career orientation. The first protean scale, self-directed protean career orientation, comprised eight items, while the second protean scale, values-driven protean career orientation, had six items. On the other hand, career goal development was assessed using four questions developed in past studies (Noe, 1996; Zikic and Klehe, 2006). Next, career satisfaction was evaluated using five items (Greenhaus et al., 1990). Lastly, Berkman's (1971a, 1971b) 8-item Index of Psychological Well-Being was used to measure psychological well-being. Ratings were based on a 5-point Likert scale $(1=$ strongly disagree to $5=$ strongly agree) for all the variables in this research. in comparison to other first-generation techniques. Furthermore PLS, as a variance-based SEM, is preferred because covariance-based SEMs presume that the observed measures have a random error variance and they assess specific variance components that are not of theoretical interest and hence, excluded from the measurement model. Nonetheless, PLSSEM presumes that the explanation of all the observed and measured variances is useful.

\section{Results}

\section{Descriptive statistics of the latent constructs}

The mean and standard deviation values of all the four latent variables ranged from 3.62 to 4.13 and 0.71 to 0.89 , respectively, based on a 5-point Likert-type scale (Table 1). Nevertheless, all the variables' mean values were above the midpoint value of 2.50. Career goal development scored the highest (4.13), while career satisfaction had the lowest (3.62). The dispersion values reported through a standard deviation indicated that the highest value, 0.89 , was shown by psychological well-being, whereas the lowest value, 0.71 , was by protean career orientation.

Table 1. Results of Descriptive Analysis

\begin{tabular}{llll}
\hline Variable & No. of items & Mean & $\begin{array}{l}\text { Std. devia- } \\
\text { tion }\end{array}$ \\
\hline Protean Career Orientation & 14 & 3.90 & 0.71 \\
\hline Career Goal Developmentw & 4 & 4.13 & 0.78 \\
\hline Career Satisfaction & 5 & 3.62 & 0.81 \\
\hline Psychological Well-Being & 8 & 3.71 & 0.89 \\
\hline
\end{tabular}

\section{Data Analysis}

The partial least square (PLS) method was employed to analyse data using SmartPLS (Henseler et al., 2009). This method was used since it possessed numerous advantages

\section{Common Method Variance}

Harman's single factor test was carried out to determine the extent of the common method bias. The principal component factor's unrotated analysis showed 
Gadjah Mada International Journal of Business - Jan-April, Vol. 22, No. 1, 2020

that the first factor accounted for 30.3\% of the total covariance of $64.9 \%$. The result signifies that the first factor accounted less than $50 \%$ of the total variance explained. Following Podsakoff et al., (2003), this implies that there is no serious issue of common method bias in this study.

\section{Model Testing}

A two-step method was employed to test the conceptual model. This approach was chosen because Anderson and Gerbing (1988) and Chin (2010) recommended that the measurement model should be analysed first, followed by the structural model. Via this approach, the validity and fit of the construct's measurements can be evaluated, prior to assessing the path coefficients or relationships among the structural model's constructs. Next, the convergent validity and discriminant validity were evaluated to confirm the construct's validity by examining the findings of the measurement model.

\section{Convergent Validity}

Cross-loadings, average variance extracted (AVE), and composite reliability were assessed to confirm the convergent validity (Table 2). As described by Fornell and Larcker (1981), AVE is the mean-variance extracted for the items loading on a construct and is a summary indicator of convergence. An AVE value of at least 0.5 implies adequate convergent validity, i.e. a latent variable can explain more than half of the variance of its indicators on average (Goetz et al., 2009). On the other hand, composite reliability is evaluated for reliability, which is a measure of convergent validity. According to Nunnally and Bernstein (1994), the composite reliability value must be above 0.7 to ensure an accurate scale. The measurement model's findings revealed that all the constructs yielded acceptable internal consistency and reliability: protean career orientation (0.88); career goal development (0.92); career satisfaction (0.86); and psychological well-being (0.77) (Table 2).

Table 2. Results of the Measurement Model

\begin{tabular}{|c|c|c|c|c|}
\hline Construct & Item & Loadings & $\mathrm{AVE}^{\mathrm{a}}$ & $\mathrm{CR}^{\mathrm{b}}$ \\
\hline \multirow{14}{*}{$\begin{array}{l}\text { Protean Career } \\
\text { Orientation }\end{array}$} & PCO_1 & 0.77 & \multirow[t]{14}{*}{0.74} & \multirow[t]{14}{*}{0.88} \\
\hline & PCO_2 & 0.81 & & \\
\hline & PCO_3 & 0.72 & & \\
\hline & PCO_4 & 0.86 & & \\
\hline & PCO_5 & 0.88 & & \\
\hline & PCO_6 & 0.79 & & \\
\hline & PCO_7 & 0.76 & & \\
\hline & PCO_8 & 0.75 & & \\
\hline & PCO_9 & 0.66 & & \\
\hline & PCO_10 & 0.75 & & \\
\hline & PCO_11 & 0.83 & & \\
\hline & PCO_12 & 0.84 & & \\
\hline & PCO_13 & 0.86 & & \\
\hline & PCO_14 & 0.82 & & \\
\hline
\end{tabular}




\begin{tabular}{|c|c|c|c|c|}
\hline \multirow{4}{*}{$\begin{array}{l}\text { Career Goal Devel- } \\
\text { opment }\end{array}$} & CGD_1 & 0.82 & \multirow[t]{4}{*}{0.72} & \multirow[t]{4}{*}{0.92} \\
\hline & CGD_2 & 0.70 & & \\
\hline & CGD_3 & 0.83 & & \\
\hline & GCD_4 & 0.78 & & \\
\hline \multirow[t]{5}{*}{ Career Satisfaction } & CSAT_1 & 0.88 & \multirow[t]{5}{*}{0.69} & \multirow[t]{5}{*}{0.86} \\
\hline & CSAT_2 & 0.81 & & \\
\hline & CSAT_3 & 0.80 & & \\
\hline & CSAT_4 & 0.73 & & \\
\hline & CSAT_5 & 0.88 & & \\
\hline \multirow{8}{*}{$\begin{array}{l}\text { Psychological } \\
\text { Well-Being }\end{array}$} & PsyWB_1 & 0.71 & \multirow[t]{8}{*}{0.76} & \multirow[t]{8}{*}{0.77} \\
\hline & PsyWB_2 & 0.69 & & \\
\hline & PsyWB_3 & 0.70 & & \\
\hline & PsyWB_4 & 0.88 & & \\
\hline & PsyWB_5 & 0.81 & & \\
\hline & PsyWB_6 & 0.83 & & \\
\hline & PsyWB_7 & 0.73 & & \\
\hline & PsyWB_8 & 0.80 & & \\
\hline
\end{tabular}

Note.

a. Average variance extracted (AVE) $=$ (summation of the square of the factor loadings) $/$ \{ (summation of the square of the factor loadings) + (summation of the error variances) $\}$

b. Composite reliability $(\mathrm{CR})=$ (square of the summation of the factor loading) / \{(square of the summation of the factor loading) + (square of the summation of the error variances) $\}$

\section{Discriminant Validity}

Discriminant validity is evaluated based on the heterotrait-monotrait (HTMT) ratio of correlations criteria in comparison to Fornell-Lacker's criterion and cross-loading factors since it performs better than traditional approaches for discriminant validity assessments (Hair et al., 2011). HTMT is a recent and conservative approach in the PLS-SEM literature for assessing the dependent variable (Henseler, Ringle, and Sarstedt, 2015). According to Hair et al., (2010), discriminant validity is the "extent to which a construct is truly distinct from other constructs by empirical standards.' To attain a satisfactory level of discriminant validity, Henseler et al., (2015) recommended an HTMT value of 0.90 , i.e. a value above 0.90 highlights a lack of DV, which implies that the constructs are conceptually similar. The findings of this study indicated that HTMT was established at HTMT.90. All the constructs \{protean career orientation (self-directed and values-driven), career goal development, career satisfaction, and psychological well-being $\}$ had an HTMT score of less than 0.90 (Table 3).

Table 3. Discriminant Validity: HTMT Criterion

\begin{tabular}{lllll}
\hline Construct & $(1)$ & $(2)$ & (3) & (4) \\
\hline (1) Protean Career Orientation & & & \\
\hline (2) Career Goal Development & 0.71 & & \\
\hline (3) Career Satisfaction & 0.70 & 0.61 & \\
\hline (4) Psychological Well-being & 0.62 & 0.89 & 0.78 \\
\hline
\end{tabular}


Gadjah Mada International Journal of Business - Jan.-April, Vol. 22, No. 1, 2020

Hypothesis Testing: Protean Career Orientation and Career Goal Development

To examine the relationship between protean career orientation and career goal development, one hypothesis was formulated and it has been supported by the findings. Hence, career goal development is positively influenced by protean career orientation $(\beta=$ $0.53, \mathrm{p}<0.01$ ), thus, supporting H1 (Table 4). well-being. As presented in Table 6, career goal development positively influences psychological well-being $(\beta=0.37$, $\mathrm{p}<0.01)$. Therefore, H3 is supported.

\section{Hypothesis Testing for Mediation} Paths

To test the mediating effect of career goal development between protean career orientation and the well-being outcomes (ca-

Table 4. Path coefficient for protean career orientation and career goal development

\begin{tabular}{llllll}
\hline No. & Relationship & Path coefficient $(\beta)$ & Std. error & t-value & Decision \\
\hline H1 & PCO $--->$ CGD & 0.53 & 0.02 & $7.45^{* * *}$ & Supported \\
\hline Note: ${ }^{* * *} \mathrm{p}<0.01(2.33),{ }^{* *} \mathrm{p}<0.05$ & $(1.645),{ }^{*} \mathrm{p}<0.1(1.28)$ & (based on one-tailed test) & \\
\hline
\end{tabular}

\section{Hypothesis Testing: Career Goal De- velopment and Career Satisfaction}

To examine the relationship between career goal development and career satisfaction, one hypothesis was formulated. From the findings, career goal development is shown to positively influence career satisfaction $(\beta$ $=0.11, \mathrm{p}<0.01$ ), supporting $\mathrm{H} 2$ (Table 5). reer satisfaction and psychological well-being), the product of the coefficient approach to mediation, suggested by MacKinnon et al., (2007) was applied. The magnitude of the joint pathway was calculated by multiplying the regression coefficient of the two segments $\left(a^{*} b\right)$. To further examine the significance of the mediation path $(a * b)$, the sum of $a * b$ was divided by the standard deviation of $\mathrm{a}^{*} \mathrm{~b}$. The results are accepted, at least at the $\mathrm{p}<0.1$

Table 5. Path coefficient for career goal development and career satisfaction

\begin{tabular}{llllll}
\hline No. & Relationship & Path coefficient $(\beta)$ & Std. error & t-value & Decision \\
\hline H2 & CGD --- $>$ CSAT & 0.11 & 0.06 & $1.53^{*}$ & Supported \\
\hline Note: ${ }^{* * *} \mathrm{p}<0.01(2.33),{ }^{* *} \mathrm{p}<0.05$ & $(1.645),{ }^{*} \mathrm{p}<0.1$ & $(1.28)$ & (based on one-tailed test) & \\
\hline
\end{tabular}

Hypothesis Testing: Career Goal Development and Psychological Well-being

One hypothesis was formulated to investigate the relationship between career goal development and psychological level $(t=1.28)$ (Efron and Tibshirani, 1993). The above approach is in contrast to the commonly used Baron and Kenny's (1989) causal steps approach. This is because 'mediation analysis as practiced in the 21 st century no longer imposes evidence of a simple association between X and Y' (Hayes, 2013,

Table 6. Path coefficient for career goal development and psychological well-being

\begin{tabular}{llllll}
\hline No. & Relationship & Path coefficient $(\beta)$ & Std. error & t-value & Decision \\
\hline H3 & CGD --- $>$ PsyWB & 0.37 & 0.07 & $4.52^{* * *}$ & Supported \\
\hline Note: ${ }^{* * *} \mathrm{p}$ & $<0.01(2.33),{ }^{* *} \mathrm{p}<0.05$ & $(1.645),{ }^{*} \mathrm{p}<0.1(1.28)$ & (based on one-tailed test) & \\
\hline
\end{tabular}


p. 88). Supported by Zhao, Lynch, and Chen (2010), the idea behind the modern approach to mediation analysis is that 'there need not be a significant zero-order effect of $\mathrm{X}$ on $\mathrm{Y}$, rxy, to establish mediation' (Zhao et al., 2010, p. 199). As a result, the mediation analysis for this study is based on the modern approach, popularized by MacKinnon et al., (2007).

Two hypotheses were postulated for the mediation of career goal development between protean career orientation and the well-being outcomes. The results showed that career goal development does not mediate the relationship between protean career orientation and career satisfaction. Therefore, $\mathrm{H} 4$ $(\beta=0.009, p>0.1)$ is rejected. Similarly, the results showed that career goal development does not mediate the relationship between protean career orientation and psychological well-being. Therefore, H5 $(\beta=0.003, \mathrm{p}$ $>0.1)$ is also rejected. The calculation of the product distribution test is shown in Table 7. satisfaction and psychological well-being.

The empirical findings revealed that protean career orientation positively influenced career goal development. This positive relationship supports the notion that employees with protean career attitudes vigorously aim for career success by translating the management of their careers into concrete actions (Hall, 2004). Briscoe and Hall (2006) stated that a protean career is mainly responsible for managing an individual's career. According to DiRenzo (2010), such a person will proactively develop a suitable career goal to autonomously direct his or her career path. Since this person possesses self-directed and values-driven attitudes, he or she will probably take the initiative to create specific goals which will allow for the fulfilment of values (Briscoe and Hall, 2006a). Moreover, he or she will also form unique goals and standards to help achieve success (Briscoe et al., 2006b). As such, a firm sense of identity and values

Table 7. Path coefficient for mediation path between protean career orientation, career goal development toward career satisfaction and psychological well-being

\begin{tabular}{lccccccc}
\hline No & Relationship & $\begin{array}{c}\text { Path a } \\
(\beta)\end{array}$ & $\begin{array}{c}\text { Path b } \\
(\beta)\end{array}$ & $\left.\begin{array}{c}\text { Indirect } \\
\text { Path }(\beta) \\
(\mathrm{a})\end{array}\right)$ & $\begin{array}{c}\text { Bootstrapped } \\
\text { Std. Dev } \\
(\mathrm{a}) \mathrm{b})\end{array}$ & t-values & Decision \\
\hline H4 & PCO -> CCG -> CSAT & 0.082 & 0.106 & 0.009 & 0.008 & 1.087 & Not Supported \\
\hline H5 & PCO -> CCG -> PsyWB & 0.065 & 0.010 & 0.003 & 0.005 & 0.013 & Not Supported \\
\hline Note. ${ }^{* * *} \mathrm{p}<0.01(2.33),{ }^{* *} \mathrm{p}<0.05(1.645),{ }^{*} \mathrm{p}<0.1(1.28)$ (based on one-tailed test) & & \\
\hline
\end{tabular}

\section{Discussion}

This research aimed to investigate the link between protean career orientation towards career goal development and well-being outcomes (career satisfaction and psychological well-being). In addition, career goal development was examined for its mediating effect between protean career orientation and well-being outcomes, which are engineers' career are imperative to guide his/her career decisions (Briscoe and Hall, 1998; Hall, 2002). Consequently, employees engage in developing career goals individually. This result concurred with that of De Vos and Soens (2008), in which protean career orientation was positively linked to career self-management behaviour. Similarly, DiRenzo's (2010) opinion that protean career orientation had a positive influence on one of proactive career management's behaviour indicators, i.e. career goal development, was supported. 
Thus, this result can justify that Malaysian professional engineers are still looking forward to attaining certain factors in their career goals' development, like promotion, increases in pay, and the development of their skills (Abdull Rahman, 2012). This outcome is influenced by the nature of the work setting in Malaysia. An organisation structures its professional engineers' key performances based on its business needs. Subsequently, increases in productivity and changes in the workplace have turned into a key part of the working life of professional engineers. Since professional engineers know their value to their organisations (Abdull Rahman, 2012), they are well-informed of new engineering developments in their field and changes to the codes and regulations. Thus, as explained by Muthuveloo and Che Rose (2005), education, training, and work experience have together created opportunities for professional engineers to increase their skill utilisation and enhance their professional development and social support. Furthermore, the CPD courses are an advantage that can assist professional engineers to maintain their professionalism in their industries. Based on these justifications, Malaysian professional engineers have career goal development behaviour irrespective of their type of protean career orientation.

The positive relationship between career goal development and career satisfaction determined in this study concurs with the results of past studies (Barnett and Bradley, 2007; Crant, 2000; and Kuijpers et al., 2006). In these previous studies, it was reported that employees who took proactive steps to realise their career goals (they engaged in career management behaviour) were more likely to experience career satisfaction. This study's respondents are professional engineers registered with BEM. At first, they were only registered as graduate engineers. To upgrade themselves to registered professional engineers, they must (a) fulfil the BEM's training requirements, (b) pass the BEM's PAE, and (c) undertake an average of 50 hours per year of CPD activities conducted by IEM. When engineers are upgraded to registered professional engineers, it can be assumed that they have engaged themselves in their career goals' development, i.e. they are individuals who have identified their career goals. By following BEM's requirements, professional engineers have programmed their behaviour accordingly. For instance, they have prepared comprehensive career development plans, they are certain about how their current position is related to their career objectives, and they are very clear regarding the efforts required to achieve their career goals. Thus, by engaging in career goal development, they will have more opportunities to be promoted and simultaneously be content with their careers. Hence, this research had shown that career goals' development positively influenced career satisfaction.

Lastly, the positive relationship between career goals' development and psychological well-being implied that professional engineers typically possess a good understanding of their career goals' development and psychological well-being. This could be due to the CPD activities which assisted them in developing highly definitive career goals. When professional engineers clearly know what they intend to accomplish, they become aware of where they must focus their efforts. Apart from that, by setting goals that are clearly defined, they can measure their accomplishments and take pride in realising those goals. Besides, the professional engineers can witness the progress of what previously seemed to be a long useless chore. This career behaviour will also increase their confidence, since the CPD activities can ex- 
pand and update their knowledge, skills and judgement, which will allow them to comprehend and apply the advancements in the art and science of engineering to endure changes in their careers' direction, be more productive, and serve the public better. Identifying their own capability in attaining the goals set will cause contentment. Hence, this new finding contributes to the literature by positing that career goal development positively influences psychological well-being.

The result of the mediation analysis showed an interesting finding. In contrast to the proposed hypothesis, the result of this study showed that career goal development did not mediate the relationship between protean career orientation and career satisfaction. Thus, it is possible to assume that the engineers in this study felt that their efforts at identifying their career goals (career goal development), have not been fully utilised. Since the engineers have established detailed career development plans, they are very clear about the efforts they need to realize their career goals. On the other hand, if their firm's management raises the critical evaluation criteria for its employees' development, or subjects them to performance evaluations and effectiveness assessments, then the professional engineers' concerns and dissatisfaction will increase. As a result, this study found that career exploration did not mediate the relationship between protean career orientation and career satisfaction.

Additionally, in contrast to the proposed hypothesis, the result of this study also showed that career goal development did not mediate the relationship between protean career orientation and psychological well-being. Thus, it is possible to assume that the engineers in this study did not implemented strategies to nurture their vitality and motiva- tion. Those strategies may include continuing their education, retraining, sabbatical leaves, rotation programmes, job transfers, and redesigning. These mechanisms are particularly important for increasing the motivation and technical vitality of older engineers, as after working for some years, they can become bored doing the same work. Besides that, without open communications, integrity, and positive reinforcement from the company, the professional values which are the key elements for the effective motivation of the engineers will be decreased. As a result, this study found that career exploration did not mediate the relationship between protean career orientation and psychological well-being.

\section{Conclusion}

The results of the findings contribute to the literature in terms of the significance of indirect relationships via the career goal development between protean career orientation towards career satisfaction and psychological well-being. These findings are different from past studies, as this study was conducted among professional engineers within the Malaysian context. The implication is that professional engineers who have a higher level of career goal development would influence their work behaviour, such as in their efforts to succeed. Employees who achieve excellent results are constantly involved in goal setting because career goals represent the motivation tools for individuals hunting for effective strategies to achieve their desired career goals efficiently. Career goal development behaviour is a positive attitude, which in turn provides a strong sense of identity and value.

Next, looking at the practical contribution, the first suggestion for graduate engineers is that they are strongly recommended to upgrade themselves to the status of pro- 
Gadjah Mada International Journal of Business - Jan-April, Vol. 22, No. 1, 2020

fessional engineers with BEM because many benefits await them. By following the requirements set by BEM, the professional engineers can programme their work behaviour accordingly. They would be considered to have established detailed career development plans. At the same time, they would be very clear about how their present position relates to their career objectives. Consequently, they would be very clear about what they need to do to achieve their career goals.

The second practical contribution is to recommend solutions for BEM to promote more continuing educational opportunities for its graduate engineers, so that they can upgrade themselves to the status of professional engineers. In addition, employers and industries could also help to encourage their unlicensed engineers to register as graduate engineers, so that later they can upgrade themselves to be professional engineers with BEM. Indirectly, this would allow them to find their jobs meaningful, and consequently, increase their work happiness.

This research has several limitations. Firstly, this study's data were self-reported; therefore Harman's single factor test was car- ried out to approximate the possible risk when interpreting the results. Second, since this is a cross-sectional study, its outcomes can vary if performed using a longitudinal method. Third, the present study did not use demographic variables such as age, years' service in the present organisation, or total length of service when analysing the results. Future studies would need to use these demographic variables as predictors of the protean career or as the control variable for the protean career, to gain a more comprehensive understanding.

Future research should conduct in-depth interviews and focus group sessions with professional engineers to find out other aspects that could enhance their protean career orientation, career goals' development, career satisfaction and psychological well-being in Malaysia. For every research model, longitudinal studies give solid inferences and better evidence and thus it would be beneficial if this research is conducted using a longitudinal approach. Furthermore, a comparative study between public and private organisations should be made, to determine which culture is more dominant. Future studies can 


\section{References}

Abdull Rahman,R. H. (2012). The impact of buman resource strategies on the retention of

engineers in Malaysian firms. (Unpublished doctoral dissertation). The University of New South Wales, Australia.

Abele, A. E., and Wiese, B. S. (2008). The homological network of self-management strategies and career success. Journal of Occupational and Organizational Psychology, 81(4), 733-749.

Anderson, J., and Gerbing, W., (1988). Structural equation modelling in practice: A review and recommended two stage approach. Psychological Bulletin, 27(1), 5-24.

Ashleigh, M.J., Higgs, M. and Dulewicz, V. 2012, 'A new propensity to trust scale and its relationship with individual well-being: implications for HRM policies and practices', The Human Resource Management Journal, 22 (4), 360-76.

Barnett, B.R. and Bradley, L. (2007). The impact of organisational support for career development on career satisfaction. Career Development International, 12(7), 617-636.

Berkman, P. L. (1971a). Life stress and psychological well-being: A replication of Langer's analysis in the midtown Manhattan study. Journal of Health and Social Behaviour, 12(1),35-45.

Berkman, P. L. (1971b). Measurement of mental health in a general population survey.

American Journal of Epidemiology, 94(2), 105-111.

Board of Engineers Malaysia. (2002).Engineers in nation building. Kuala Lumpur, Malaysia: Author. Retrieved from http://www.bem.org.my/v3/publications. html

Briscoe, J. P., and Hall, D. T. (2006a). Special section on boundary less and protean careers: Next steps in conceptualizing and measuring boundary less and protean careers. Journal of Vocational Behaviour, 69(1), 1-3.

Briscoe, J. P., and Hall, D. T. (2006b). The interplay of boundary less and protean careers: Combinations and implications. Journal of Vocational Behaviour, 69(1), 4-18.

Cha, J., Kim, S. J., Beck, J., and Knutson, B. J. (2017). Predictors of career success among lodging revenue managers: Investigating roles of proactive work behaviors. International Journal of Hospitality and Tourism Administration, 18(4), 474-490.

Chin, W. W. (2010). How to write up and report PLS analyses. In V. Esposito, W. W. Chin, J. Henseler, and H. Wang (Eds.), Handbook of partial least squares (pp. 655-688). New York, NY: Springer-Verlag.

Crant, J. M. (2000). Proactive behaviour in organizations. Journal of Management, 26(3), 435-462. 
Gadjah Mada International Journal of Business - Jan.-April, Vol. 22, No. 1, 2020

De Vos, A., and Soens, N. (2008). Protean attitude and career success: The mediating role of self-management. Journal of Vocational Behavior, 73, 449-456.

Dickmann, M., Suutari, V., Brewster, C., Mäkelä, L., Tanskanen, J., and Tornikoski, C. (2018). The career competencies of self-initiated and assigned expatriates: assessing the development of career capital over time. The International Journal of Human Resource Management, 29(16), 2353-2371.

Diener, E., Lucas, R. E., and Oishi, S. (2018). Advances and open questions in the science of subjective well-being. Collabra. Psychology, 4(1).

DiRenzo, M. S. (2010). An examination of the roles of protean career orientation and career capital on work and life outcomes. (Unpublished doctoral dissertation). Drexel University. Philadelphia, PA.

Feldman, M. S. (2000). Organizational routines as a source of continuous change. Organization Science, 11(6), 611-629.

Frieder, R. E., Wang, G., and Oh, I. S. (2018). Linking job-relevant personality traits, transformational leadership, and job performance via perceived meaningfulness at work: A moderated mediation model. Journal of Applied Psychology, 103(3), 324.

Fornell, C. G., and Larcker, D. F. (1981). Evaluating structural equation models with unobservable variables and measurement error. Journal of Marketing Research, 18(1), 39-50.

Grant, A. M. and Ashford, S. J. (2008). The dynamics of proactivity at work. Research in Organizational Behaviour, 28, 3-34.

Greenhaus, J. H., Parasuraman, S., and Collins, K. M. (2001). Career involvement and family involvement as moderators of relationships between work-family conflict and withdrawal from a profession. Journal of Occupational Health Psychology, 6(2), 91-100.

Greenhaus, J. H., Parasuraman, S., and Wormley, W. M. (1990). Effects of race on organizational experiences, job performance evaluations, and career outcomes. Academy of Management Journal, 33(1), 64-86.

Goetz, O., Liehr-Gobbers, K., and Krafft, M. (2010). Evaluation of structural equation models using the partial least squares (PLS) approach. In V. Esposito, W. W. Chin, J. Henseler, and H. Wang (Eds.), Handbook of partial least squares (pp. 691-711). New York, NY: Springer-Verlag.

Guan, Y., Arthur, M. B., Khapova, S. N., Hall, R. J., and Lord, R. G. (2019). Career boundarylessness and career success: A review, integration and guide to future research. Journal of Vocational Behavior, 110, 390-402.

Hall, D. T. (1976). Careers in organizations. Glenview, IL: Scott Foresman.

Hall, D. T. (2002). Careers in and out of organizations. Thousand Oaks, CA: Sage 
Publications.

Hall, D. T., and Moss, J. E. (1998). The new protean career contract: Helping organizations and employees adapt. Organizational Dynamics, 26(3), 22-37.

Hall, D. T., Yip, J., and Doiron, K. (2018). Protean careers at work: Self-direction and values orientation in psychological success. Annual Review of Organizational Psychology and Organizational Behavior, 5, 129-156.

Hair, J. F., Black, W. C., Babin, B. J., and Anderson, R. E. (2010), Multivariate data analysis. Englewood Cliffs, NJ: Prentice Hall.

Hamid, A. R. A., Majid, M. Z. A., and Singh, B. (2008). Causes of accidents at construction sites. Malaysian journal of civil engineering, 20(2), 242-259.

Henseler, J., Ringle, C. M., and Sarstedt, M. (2015). A new criterion for assessing discriminant validity in variance-based structural equation modeling. Journal of the academy of marketing science, 43(1), 115-135.

Henseler, J., Ringle, C. M., and Sinkovics, R. R. (2009). The use of partial least squares path modeling in international marketing. In R. R. Sinkovics, P. N. Ghauri (Eds.), Advances in International Marketing (pp. 277-320). Bingley, UK: Emerald.

Hirschi, A., Herrmann, A., Nagy, N., and Spurk, D. (2016). All in the name of work? Nonwork orientations as predictors of salary, career satisfaction, and life satisfaction. Journal of vocational behavior, 95, 45-57.

Jibeen, T. (2019). Subjective Well-Being of Afghan Refugees in Pakistan: The Moderating Role of Perceived Control in Married Men. Community mental health journal, 55(1), 144-155.

Joshanloo, M. (2019). Structural and discriminant validity of the tripartite model of mental well-being: Differential relationships with the Big Five traits. Journal of Mental Health, 28(2), 168-174.

Judge, T. A., Cable, D. M., Boudreau, J.W., and Bretz, R.D. Jr. (1995). An empirical system investigation of the predictors of executive career success. PersonnelPsychology, 48, 485-519.

Kahneman, D., Diener, E and Schwarz, N. (Eds.). (1999). Well-Being: Foundations of Hedonic Psychology (pp. 434-450). New York, NY: Russell Sage Foundation.

Kelly Services. (2012).Employment outlook 2012 - Malaysia. Retrieved from http:/ /www. kellyservices.com.my/MY/About-Us/Kelly-Services-Malaysia-Employment-Outlook-and-Salary-Guide-2012/13/\#.VCpy-PmSwjU

Kraimer, M. L., Greco, L., Seibert, S. E., and Sargent, L. D. (2019). An investigation of academic career success: The new tempo of academic life. Academy of Management Learning and Education, 18(2), 128-152. 
Gadjah Mada International Journal of Business - Jan.-April, Vol. 22, No. 1, 2020

Kuijpers, M. A. C. T, Schyns, B., and Scheerens, J. (2006). Career competencies for career success. Career Development Quarterly, 55(2), 168-179.

Kwak, H., Anderson, R. E., Leigh, T. W., and Bonifield, S. D. (2019). Impact of salesperson macro-adaptive selling strategy on job performance and satisfaction. Journal of Business Research, 94, 42-55.

Latham, G. P. (2016). Goal setting: A possible theoretical framework for examining the effect priming goals on organizational behavior. Current Opinion in Psychology, 12, 85-88.

Lee, W., and Migliaccio, G. C. (2018). Temporal effect of construction workforce physical strain on diminishing marginal productivity at the task level. Journal of Construction Engineering and Management, 144(9), 04018083.

Locke, E. A. (1984). Job satisfaction. In M. Gruneberg and T. Wall (Eds.), Social psychology and organizational behaviour. Chichester, UK: Wiley.

Locke, E. A., and Shaw, K. N. (1981). Saari, LM, and Latham. P. Goal setting and task performance: i969-1980. Psychological Bulletin, 90, 125-152.

Locke, E. A., and Latham, G. P. (2006). New directions in goal-setting theory. Current Directions in Psychological Science, 15(5), 265-268.

Lo Presti, A., Pluviano, S., and Briscoe, J. P. (2018). Are freelancers a breed apart? The role of protean and boundaryless career attitudes in employability and career success. Human Resource Management Journal, 28(3), 427-442.

Lysova, E. I., Jansen, P. G., Khapova, S. N., Plomp, J., and Tims, M. (2018). Examining calling as a double-edged sword for employability. Journal of Vocational Behavior, 104, $261-272$.

Malan, M. (2004). Work-related well-being of engineers in South Africa. (Unpublished doctoral dissertation). North-West University, Africa.

Muthuveloo, R., and Che Rose, R. (2005). Antecedents and outcomes of organisational commitment among Malaysian engineers. American Journal of Applied Sciences, 2(6), 10951100.

Ngo, H. Y., and Hui, L. (2018). Individual orientations and career satisfaction: The mediating roles of work engagement and self-efficacy. Journal of Career Development, 45(5), 425-439.

Noe, R. A. (1996). Is career management related to employee development and performance? Journal of Organizational Behaviour, 17(2), 119-133.

Nunnally, J. C., and Bernstein, I. H. (1994). Psychometric theory (3rd ed.). New York, NY: McGraw-Hill.

Ogbeiwi, O. (2018). General concepts of goals and goal-setting in healthcare: A narrative review. Journal of Management and Organization, 1-18. 
Rahim, N. B., and Siti-Rohaida, M. Z. (2015). Protean Career Orientation and Career Goal Development: Do they Predict Engineer's Psychological Well-being? Procedia-Social and Behavioral Sciences, 172, 270-277.

Ryan, R. M., Huta, V., and Deci, E. L. (2008). Living well: A self-determination theory perspective on eudaimonia. Journal of Happiness Studies, 9(1), 139-170.

Ryan, R. M., Soenens, B., and Vansteenkiste, M. (2018). Reflections on self-determination theory as an organizing framework for personality psychology: Interfaces, integrations, issues, and unfinished business. Journal of personality.

Ryff, C. D. (2018). Well-being with soul: Science in pursuit of human potential. Perspectives on Psychological Science, 13(2), 242-248.

Sargent, L. D., and Domberger, S. R. (2007). Exploring the development of a protean career orientation: values and image violations. Career development international, 12(6), 545-564.

Sheldon, K. M., Corcoran, M., and Prentice, M. (2019). Pursuing Eudaimonic Functioning Versus Pursuing Hedonic Well-Being: The First Goal Succeeds in Its Aim, Whereas the Second Does Not. Journal of Happiness Studies, 20(3), 919-933.

Spurk, D., Hirschi, A., and Dries, N. (2019). Antecedents and outcomes of objective versus subjective career success: Competing perspectives and future directions. Journal of Management, 45(1), 35-69.

Stauffer, S. D., Abessolo, M., Zecca, G., and Rossier, J. (2019). French-language translation and validation of the protean and boundaryless career attitudes scales: relationships to proactive personality, career adaptability, and career satisfaction. Journal of Career, 27(2), 337-357.

Steele, J., Bourke, L., Luloff, A. E., Liao, P. S., Theodori, G. L., and Krannich, R. S. (2001). The drop-off/pick-up method for household survey research. Community Development, 32(2), 238-250.

Sugalski, T. D., and Greenhaus, J. H. (1986). Career exploration and goal setting among managerial employees. Journal of Vocational Behavior, 29(1), 102-114.

Sun, X. (2017). Self-Compassion, Hedonic and Eudaimonic Well-Being among Hong Kong Adolescents: Selection, Optimization and Compensation as Mediators (Doctoral dissertation, The Chinese University of Hong Kong (Hong Kong).

Suvaci, B. (2018). The Impact of Organizational Culture on Employees' Protean and Boundaryless Career Attitudes: An Empirical Study of the Banking Sector in Turkey. Journal of Business and Management, 24(1).

Trevelyan, J. (2007). Technical coordination in engineering practice. Journal of Engineering Education, 96(3), 191-204.

Warr, P. (1990), The measurement of well-being and other aspects of mental health. Journal of 
Gadjah Mada International Journal of Business - Jan.-April, Vol. 22, No. 1, 2020

Occupational Psychology, 63(3), 193-210.

Wright, T. A., and Cropanzano, R. (2000). Psychological well-being and job satisfaction as predictors of job performance. Journal of Occupational Health Psychology, 5(1), 84-94.

Xueling, P. E. I. (2017). Empirical Study of Career Management and Engagement. Canadian Social Science, 13(1), 43-48.

Zikic, J., and Klehe, U. C. (2006). Job loss as a blessing in disguise: The role of career exploration and career planning in predicting reemployment quality. Journal of Vocational Behaviour, 69, 391-409. 